\title{
A EXPANSÃO DOS IMPÉRIOS EUROPEUS: VALEU A PENA?*
}

\author{
Patrick Karl O'Brien** \\ Leandro De La Escosura***
}

\section{INTRODUÇÃO}

Este ensaio examinará criticamente e tentará oferecer uma interpretação global de um crescente volume de publicações de historiadores que tentam avaliar os custos e benefícios das economias da própria Europa resultando de cinco séculos de envolvimento com impérios no exterior. Este envolvimento começou com a conquista de Ceuta pelos portugueses em 1417 e atravessou duas épocas: 1417-1825 e 1825-1974. Após a primeira conjuntura marcada pela Revolução Francesa, um quarto de século de conflitos globais e de movimentos pela independência na América do Sul, a Grã-Bretanha surgiu como a força imperial hegemônica na Europa. Seus maiores rivais no comércio e no domínio da África, Ásia e Américas (Portugal, Espanha, França e Holanda) cederam o controle de partes de suas posses no exterior para a Grã-Bretanha ou (no caso da Espanha e Portugal) perderam a soberania de suas colônias na América Latina.

Antes de 1815-1825, batalhas por comércio, bases marítimas, populações e territórios no exterior tinham persistido com freqüentes

"Este artigo é baseado em um projeto de pesquisa conjunto dos autores, cujo resultado foi apresentado no $12{ }^{\circ}$ Congresso Internacional de História Econômica (Madrid, 1998). A versão para o português foi realizada pelos professores Nilson Maciel de Paula e Maurício Aguiar Serra.

*** Professor de História Econômica da London School of Economics and Political Science.

${ }^{* * * *}$ Professor de História Econômica da Universidad Carlos III. 
interlúdios de guerras por aproximadamente quatro séculos. Em termos historiográficos, uma esmagadora parcela da história publicada do imperialismo europeu e da expansão no exterior está relacionada com a época do mercantilismo 1417-1825. ${ }^{1}$ Depois disso, e como a busca mercantilista de poder e lucro subsidiou e foi substituído pelo discurso liberal do livre comércio, economistas e outros intelectuais começaram a questionar todo o empreendimento imperialista e a considerar os custos nele envolvidos.

Naquele momento e desde então, a noção integral (que sustenta a maior parte da literatura examinada neste artigo) de construir balanços contábeis nacionais para a aquisição, expansão e retenção dos impérios europeus no exterior tem sido contestada como logicamente insustentável, principalmente para os domínios de língua inglesa no exterior. A essência desta objeção parece ser que impérios (ou pelo menos aqueles habitados por povoadores e seus descendentes da Europa) são propriamente representados como "extensões" das sociedades e economias metropolitanas. Então os ganhos advindos, por exemplo, dos povoadores ingleses na Austrália, dos pés-negros franceses na Argélia e dos residentes holandeses em Java, são descritos como ganhos "nacionais" do colonialismo e imperialismo, que não podem ser significativamente distinguidos dos benefícios econômicos que retornam através do tempo para as economias nacionais e para os bolsos dos cidadãos residentes da Inglaterra, França, Holanda e outros países europeus. Caso esta representação dos impérios (como a França, Portugal, Espanha, Holanda ou Grã-Bretanha além-mar) seja aceita, então realmente a construção dos balanços contábeis nacionais torna-se redundante. Não poderiam existir ganhos separáveis resultando de decisões políticas tomadas e por uma série de políticas imperiais implementadas pelas potências européias ao longo do tempo para adquirir, expandir e continuar a governar colônias e domínios no exterior.

Por outro lado, existe, entretanto, uma tradição de debate político e de discurso histórico que insiste que os "desembolsos" e os "retornos", resultantes do imperialismo formal e da manutenção das conexões imperiais para as economias nacionais da Europa, podem ser combinados e discutidos como um exercício de contabilidade macroeconômica. Realmente, do tempo de Adam Smith em diante, intelectuais europeus fizeram

1 Ver a maciça bibliografia incluída na nova série editada por RUSSELLWOOD, J. R. (Ed.). An expanding world. The European impact on world history 14501800. Aldershot, 1995. 
avaliações que separaram os interesses de uma metrópole dos interesses de suas colônias, domínios e possessões no exterior. ${ }^{2}$ Este exame se propõe a continuar na maneira tradicional, concentrando-se (ver terceira e quarta seções) sobre os custos macroeconômicos e os benefícios dos impérios para o crescimento econômico em longo prazo de várias economias européias, posto que elas primeiro se desenvolveram durante o século XIX, 1815-1914, e subseqüentemente durante períodos de reintegração imperial e descolonização inaugurada por duas conjunturas - marcadas pelas guerras mundiais do século XX.

\section{GANHOS MACROECONÔMICOS DA EUROPA DA PRIMEIRA ERA DO IMPERIALISMO, 1417-1815}

A primeira época do imperialismo europeu começou com a colonização de Ceuta em 1417 e terminou com o Tratado de Viena, quando a França, Espanha, Portugal (e mesmo a Holanda) virtualmente perderam a maioria dos seus impérios no exterior. Ainda que naquela conjuntura fosse óbvio que, sem aproximadamente quatro séculos de expansão da potência européia na África, Ásia e acima de tudo nas Américas, todas as economias da Europa teriam sido mais pobres, a composição de seus produtos nacionais teria sido mais agrícola e menos industrial na forma, menores proporções de suas forças de trabalho teriam sido empregadas na indústria e residiriam nas cidades. Ao longo do tempo as sociedades e economias européias tinham obtido ganhos do imperialismo, que tomaram a forma tangível de gêneros alimentícios, matérias-primas, minerais e mercadorias manufaturadas importadas de outros continentes que desaguavam nos portos europeus - oscilante a princípio -, mas rapidamente quando seus preços e custos caíram depois de 1650. A lista inclui comestíveis tropicais (pimenta, canela, cravo-da-índia, noz-moscada, gengibre, cacau, café, chá, açúcar, planta do amendoim e tabaco), gêneros alimentícios básicos (peixe e óleos de peixe, milho, batatas, tomates, feijões, pimentões, ruibarbo), remédios botânicos (cocaína, quinino, narcóticos), matérias-primas industriais

2 OFFER não parece convencido pela tradição polêmica examinada por WOOD, J. C. British economists and empire. 1993, que é baseada na suposição de que os custos e benefícios dos impérios são separáveis na maneira proposta por este ensaio OFFER, A. Costs and benefits, peace and war 1870-1914. In: PORTER, A. (Ed.). The Oxford history of the British Empire. Oxford, 1999. p. 690-711. 
(madeiras-de-lei, seda, fibras de algodão, peles, ceras, índigo, cochinilha e outras matérias corantes), manufaturas (porcelana, jóias, têxteis) e, acima de tudo, prata e ouro da América do Sul. ${ }^{3}$

Mesmo assim, a importância macroeconômica e as ramificações dessas concretas manifestações de generosidade do comércio e do império permanecem difíceis de se analisar e impossíveis de se quantificar. Várias indústrias européias eram baseadas na substituição de importações de produtos originalmente trazidos da Ásia e do mundo islâmico - incluindo seda, tecidos de algodão, porcelana e jóias. Além disso, a formação de capital, o estabelecimento de firmas e o emprego da mão-de-obra tinham ocorrido para processar as matérias-primas importadas de outros continentes para os portos europeus e tinham levado ao desenvolvimento de novas indústrias, incluindo tecidos de seda e algodão, tintura, estampagem e acabamento de roupas, mobília feita de madeiras-de-lei, refino de açúcar, torração de café, processamento de tabaco e fabrico do chocolate. As especiarias importadas, os pimentões, os tomates, o café, o chá, o cacau e, acima de tudo, o açúcar, não somente trouxeram diversidade para uma monótona dieta européia como (juntamente com as propriedades curativas e energéticas de remédios botânicos tais como chá, ruibarbo, quinino, e óleos de peixe) aumentaram as propensões e as capacidades de trabalho da mão-de-obra nacional. Mais significativos foram os acréscimos calóricos ao básico suprimento alimentar e o crescimento eventual das populações e cidades promovido pela introdução do milho, das batatas e do peixe (pescado nas distantes águas do Atlântico). Os retornos oriundos do comércio imperial para a expansão de Hamburgo e para a construção naval, a marinha mercante e os serviços financeiros e comerciais que formaram os principais portos como Sevilha, Cádiz, Lisboa, Antuérpia, Amsterdã, Bordeaux, Londres, Bristol, Glasgow resultaram no desenvolvimento e na prosperidade de suas regiões periféricas, ainda visíveis nos dias de hoje. ${ }^{4}$

Embora as maciças importações de metais preciosos das Américas e da África sejam consideradas pelos historiadores como redutores das perspectivas para o desenvolvimento em longo prazo de Espanha e Portugal, as barras de ouro e prata vieram a ser úteis para o desenvolvimento de um

3 FISCHER, W.; McINNIS, R. M.; SCHNEIDER, J. (Ed.). The emergence of a world economy 1500-1850. Stuttgart, 1986.

4 BRAUDEL, F. The perspective of the world. 1979. 
sistema monetário europeu e internacional. ${ }^{5}$ Cunhados em moedas e amplamente aceitos como instrumentos secundários de crédito e circulação de papel, a prata e o ouro, principalmente da América do Sul e, em menor escala, da África, forneceram a base para a necessária expansão no provimento do dinheiro nacional e internacional. Sem esta flexibilidade e porque os bens primários e estratégicos produzidos nas economias bálticas não podiam ser cobertos pelas exportações de mercadorias, o comércio intra-europeu, desde a Europa Setentrional até a Ocidental e o Mediterrâneo, teria sido certamente limitado. ${ }^{6}$

O comércio com a China, a Índia e com outras partes da Ásia também poderia ter sido seriamente reduzido em função dos longos períodos dos séculos XVI, XVII e XVIII, em que aproximadamente três quartos das mercadorias compradas na Ásia não poderiam ser cobertas pelas rendas recebidas das exportações das mercadorias da Europa. ${ }^{7}$ Barras de ouro e de prata, desaguando na Península Ibérica, agiram como o dólar do dia. Os europeus obtiveram a prata que necessitavam para comercializar com o Báltico, Ásia e entre eles porque os ibéricos obtinham déficits nas suas balanças de pagamento. Isto estabilizou as economias européias e facilitou suas transformações graduais. ${ }^{8}$

Além disso, o poder dos Habsburgo (fundado pela prata americana) deteve o golpe do imperialismo otomano no Mediterrâneo oriental e nos Bálcãs. (Os exércitos turcos resistiram nos portões de Viena por duas vezes: em 1529 e novamente em 1683). ${ }^{9}$ Neste ínterim, as pretensões de Carlos V e Filipe II de uma monarquia universal (também encorajados pelas pilhagens do Novo Mundo) reforçaram a convicção tradicional dos europeus de que politicamente o continente deles deveria desenvolver-se como um sistema multiestatal e não em algum novo império romano, sagrado,

5 FORSYTH, P. J.; NICHOLAS, S. J. The decline of Spanish industry and the price revolution: a neo-classical analysis. Jnl. Eur. Econ. Hist., p. 601-610, 1983.

6 STEENSGAARD, N. Commodities, bullion and services in intercontinental transactions before 1750. In: POHL, H. (Ed.). The European discovery of the world and its economic effects on pre-industrial society. Stuttgart, 1990. p. 9-24.

7 BARRETT, W. World bullion flows. In: TRACY, J. (Ed.). The rise of merchant empires. Cambridge, 1990. p. 224-234.

8 FLYNN, D.; GIRALDEZ, A. (Ed.). Metals and monies in an emerging global economy. Aldershot, 1996.

9 PARKER, G. Europe and the wider world 1500-1700: the miliary balance. In: TRACY, J. (Ed.). The political economy of merchant empires. Cambridge, 1991. p. 161195. 
governado de Madrid, Viena ou Paris..$^{10} \mathrm{O}$ peculiar sistema estatal da Europa, com suas rivalidades e um equilíbrio de poder dispendiosamente mantido, contribuiu positivamente para o crescimento econômico ao promover difusões de pessoas, capitais, conhecimentos e tecnologias úteis através das fronteiras. ${ }^{11}$

Por caminhos complexos, o imperialismo da era mercantilista ajudou a colocar as já interconectadas economias da Europa Ocidental sobre uma trilha que, por volta de 1914, forneceu às suas populações padrões de vida marcadamente mais elevados do que o resto do mundo. Contudo, os argumentos que reificam a expansão ultramarina européia como uma máquina de progresso econômico devem ser fortemente qualificados. Por exemplo, esse motor (conquista e comércio) em particular pouco fez para promover a industrialização na Península Ibérica. ${ }^{12}$ Historiadores espanhóis e portugueses parecem mais inclinados a considerar as conexões já existentes de suas nações com os impérios na Ásia e nas Américas como responsáveis pelas lentas transições dessas economias para o estágio industrial. ${ }^{13} \mathrm{~A}$ França (ou mesmo seus portos ocidentais e hinterlândias) obteve claros benefícios dos investimentos no comércio transatlântico e da colonização durante o século XVIII. Entretanto, os potenciais retornos da França diminuíram acentuadamente quando o Estado Bourbon perdeu o Canadá e suas bases na Índia, durante a Guerra dos Sete Anos. ${ }^{14}$ Eles ficaram reduzidos à insignificância depois da destruição das ricas plantações da colônia do Haiti e a perda de outras ilhas caribenhas para a Grã-Bretanha durante a guerra de 1793-1815. ${ }^{15}$ Por mais de um século, o sucesso das Províncias Unidas na exploração das oportunidades oferecidas pelo comércio internacional e pela colonização provocou o antagonismo de rivais, particularmente Grã-Bretanha e França, que utilizaram forças naval e militar para enfraquecer o poder e a

10 TILLY, C. Coercion, capital and states. Oxford, 1990.

11 JONES, E. L. The European miracle. Cambridge, 1981. p. 104-153.

12 YUN-CASALILLA, B. The American empire and the Spanish economy: an institutional and regional perspective. Revista de Historia Económica, n. 1, p. 123-157, 1998; e PEREIRA, J. M. To have and to have not. The economic consequences of empire. Revista de Historia Económica, v. 16, p. 93-122, 1998.

13 PEREIRA, J. M. La economía portuguesa y el fin del imperio luso brasileño. In: PRADOS DE LA ESCOSURA, L.; AMARAL, S. (Ed.). La independencia americana: consecuencias. Madrid, 1993. p. 219-252; e THOMPSON, I.; YUN-CASALILLA, B. (Ed.). The Castillian crisis of the seventeenth century. Cambridge, 1994.

14 BUTEL, P.; CROUZET, F. Empire and economic growth: the case of France. Revista de Historia Económica, v. 1, p. 177-194, 1998.

15 BUTEL, P. France, the Antilles and Europe in the seventeenth and eighteenth centuries: renewals of foreign trade. In: TRACY, 1990, op. cit., p. 153-174. 
economia da República. ${ }^{16}$ Então, os mercadores holandeses e o capital desempenharam um papel ao ajudar a Grã-Bretanha a ascender a uma posição hegemônica na economia global em expansão. ${ }^{17}$

Ainda assim, para a Inglaterra (onde a industrialização, entre a Guerra Civil e a vitória pelo livre comércio, cerca de dois séculos mais tarde, pode ser mais claramente associada com o imperialismo), a importância macroeconômica de seus benefícios não deve ser exagerada. ${ }^{18}$ Sim: uma elevada, mas não dominante, parcela de todo o produto industrial excedente manufaturado na Grã-Bretanha durante as etapas iniciais da industrialização, 1660-1815, foi exportada para o exterior, principalmente para as Américas, Ásia e África. Para o que deve-se adicionar uma proporção das exportações vendidas para outros países europeus, que derivaram de suas próprias participações no comércio mundial suas capacidades para gastar em bens britânicos. ${ }^{19}$ Os lucros oriundos dessa atividade comercial ajudaram a financiar a expansão da indústria britânica, a promover investimentos nos transportes internos, a desenvolver a intermediação financeira, a expandir a distribuição e outras redes intimamente associadas à indústria. Eles promoveram o crescimento do capital destinado para moradias e gastos sociais, requerido para apoiar o extraordinário crescimento de Londres e de outras cidades portuárias. Os mercadores britânicos tornaram-se bem sucedidos empresários, banqueiros e membros do Parlamento. Eles pressionaram os governos aristocráticos para criar condições ficais, legais e institucionais para uma operação mais eficiente da mercadoria, do capital e dos mercados de trabalho.

As receitas das exportações forneceram as condições para a obtenção de mercadorias importadas estratégicas, incluindo madeira, piche, alcatrão, cânhamo e ferro em barra, tanto quanto importantes matériasprimas, tais como seda, linho, algodão, matéria corante e açúcar. Os bens de luxo importados (tabaco, chá, bebidas alcoólicas e tecidos de alta qualidade) forneceram incentivos para um trabalho mais árduo, contribuíram para aumentar as receitas do Ministério da Fazenda com taxas alfandegárias

16 EMMER, P. C. The economic impact of the Dutch expansion overseas 1570-1870. Revista de Historia Económica, v. 16, p. 157-176, 1998.

17 DE VRIES, J.; VAN DER WOUDE, A. The first modern economy. Success and perseverance of the dutch economy. Cambridge, 1997.

18 ENGERMAN, S. L. British imperialism in a mercantilist age 1492-1849: conceptual issues and empirical problems. Revista de Historia Económica, v. 16, p. 195-234, 1998.

19 CUENCA ESTEBAN, J. The rising share of British industrial exports in industrial output, 1700-1851. Jnl. Econ. Hist., n. 57, p. 879-906, 1997. 
e financiaram a poderosa marinha de guerra exigida para a segurança do reino e para a proteção do comércio e da expansão territorial ultramarina. ${ }^{20}$

Contudo, outros (e provavelmente mais significantes) fatores endógenos também continuaram a operar, incluindo a agricultura altamente produtiva do reino, seu depósito de energia barata e a acumulação de uma mão-de-obra qualificada capaz de inventar, desenvolver e trabalhar com novas maquinarias. A Grã-Bretanha tinha participado do comércio intraeuropeu e na troca de conhecimento técnico e científico por séculos antes de Colombo, Da Gama e de outros navegadores que iniciaram suas viagens de descoberta. ${ }^{21}$ Finalmente, as guerras Revolucionária e Napoleônica deprimiram as economias, interromperam o comércio e virtualmente colocaram um fim para os impérios de todos os competidores britânicos, particularmente a França, mas também Espanha e Portugal. No Congresso de Viena, um general austríaco observou que a

Grã-Bretanha não tinha maiores obrigações para com qualquer mortal na terra do que este rufião (Napoleão). Através dos acontecimentos que ele realizou, a grandeza, a prosperidade e a riqueza da Inglaterra aumentaram extremamente. Ela é senhora do mar e não tem um único rival para temer nem em seu domínio nem em seu comércio mundial. ${ }^{22}$

\section{OS IMPÉRIOS EUROPEUS DURANTE A ORDEM INTERNACIONAL LIBERAL, 1846-1914}

Uma vez que as guerras revolucionárias perderam o viço na história, os liberais intelectuais retornaram ao argumento de que, desde que o equilíbrio de poder dentro da Europa tinha sido assegurado e porque a ordem econômica internacional estava se movendo na direção do livre comércio, a retenção (deixando de lado a expansão) dos impérios podia ser somente contraprodutiva

20 O'BRIEN, P. K.; ENGERMAN, S. L. Exports and the growth of the British economy from the Glorious Revolution to the Peace of Amiens. In: SOLOW, B. (Ed.). Slavery and the rise of the Atlantic system. Cambridge, 1991. p. 177-209.

21 O'BRIEN, P. K. Inseparable connections: trade, economy, fiscal state and the expansion of empire. In: MARSHALL, P. (Ed.). The Oxford history of the British empire. Oxford, 1998. v. 2, p. 53-78.

22 Citado por: KENNEDY, P. The rise and fall of British naval mastery. 1983. 
para a vitalidade das economias da Europa. Tais argumentos tinham aparecido nos argumentos de Adam Smith nos anos 70 (do século dezoito) e no polêmico "Emancipate Your Colonies" de Jeremy Bentham`s apresentado na deflagração da guerra em 1793. ${ }^{23}$ Por várias décadas no século dezenove, as recomendações de "Cobdenite" para cortar os laços políticos formais entre os estados europeus e suas colônias no estrangeiro receberam algo como uma solidária audiência de estadistas e da opinião pública. Ainda, por décadas e décadas após a perda das colônias ibéricas na América do Sul (e particularmente durante a maré alta do imperialismo europeu, 1882-1903), os impérios continuaram a se expandir semelhantemente sob governos liberais, conservadores e autocráticos. Dinamarca, Suécia e Holanda venderam suas colônias no estrangeiro para a Grã-Bretanha, a França e os Estados Unidos, e as concessões para o alto governo local marcaram as relações políticas entre governos metropolitanos e seus "impérios". Contudo, nenhum território foi realmente abandonado até depois da Segunda Guerra Mundial. Desta maneira, em 1815, a Europa e as possessões européias e povoamentos no estrangeiro ocupavam $55 \%$ da superfície mundial; em 1878, 67\%, e por volta de 1914 (quando as únicas partes do mundo que nunca tinham sido colonizadas incluíam China, Japão, Sião, Arábia, Tibete, Mongólia e Turquia) esta porcentagem aumentou para um surpreendente $84 \%{ }^{24}$

A expansão ultramarina (e por terra) chegou virtualmente a um fim com a deflagração do conflito armado destrutivo entre as grandes potências, 1914-1918 - uma conjuntura que marcou o início e o fim de cinco séculos de imperialismo europeu. Por um breve interlúdio entre 1846 e 1914 (e num contexto de uma ordem internacional viável para a conduta das políticas das grandes potências e de condições pacíficas para relações econômicas transnacionais), os custos, tanto quanto os benefícios dos impérios, foram analisados com o propósito de informar os debates nacionais e internacionais, relacionados com a base política, econômica e moral das políticas comercial e imperial, levadas adiante pelas maiores potências européias. ${ }^{25}$ Esse discurso foi recentemente revivido nos escritos dos historiadores econômicos da Europa Ocidental e está preocupado em avaliar e medir as ligações entre o imperialismo no estrangeiro e a vitalidade de várias economias metropolitanas. Os historiadores usaram uma matriz de contas nacionais para analisar as conexões entre os impérios e o

23 GOMES, L. Foreign trade and the national economy. 1987. p. 63.

24 BERGESEN. Studies of the Modern World System. p. 237-238; e CLARK, G. The balance sheet of imperialism. New York, 1936. p. 23-28.

25 PORTER, B. Critics of Empire. 1968. 
crescimento macroeconômico de várias economias nacionais que inclui dados de balança de pagamentos, estimativas dos retornos do capital privado investido nas colônias, imigração e a alocação dos impostos cobrados das sociedades metropolitanas, com propósitos de preservar a segurança dos estados e suas possessões nacionais no estrangeiro. ${ }^{26}$ Em teoria, a escala e a importância de tais ligações (emergindo por meio dos fluxos de comércio, capital, trabalho e gastos dos governos metropolitanos em defesa e outros objetivos imperiais) poderiam ser quantificadas e avaliadas em termos dos seus impactos sobre o crescimento de qualquer economia européia no longo prazo. ${ }^{27}$ As conexões, fluindo dos "elementos imperiais" na formulação de um (teoricamente separável) conjunto de políticas fiscais, monetárias e estratégicas "puramente domésticas", são comumente discerníveis, mas raramente quantificáveis, enquanto influências mais sutis, moldadas pela "infiltração" de uma dimensão imperial nas políticas nacionais, nas culturas, nas instituições e nas preferências dos consumidores, simplesmente promovem debates insolúveis numa contínua avaliação dos impérios europeus.

Enquanto isso, tanto as parcelas das exportações das mercadorias vendidas quanto a das importações compradas de vários impérios europeus parecem ser o único indicador comparativo correntemente disponível para se comparar à importância econômica dos domínios, colônias e dependências antes de 1914. Os fluxos comerciais e outros indicadores parciais, como a perda das colônias na América do Sul, revelam que a significância macroeconômica do império para o apogeu, crescimento e queda da economia britânica permaneceu bem maior e persistiu muito mais do que para qualquer outra nação na Europa, com a possível exceção de Portugal. ${ }^{28} \mathrm{O}$ breve envolvimento da economia espanhola com o império após 1825 pode mesmo ter tido efeitos benéficos sobre a taxa de crescimento econômico no longo prazo. ${ }^{29}$ Embora o estado espanhol retivesse e renovasse seus compromissos com suas colônias remanescentes por várias décadas no século dezenove, qualquer potencial para ganhos advindos do colonialismo ficou reduzido à insignificância após as perdas adicionais de Cuba, Porto Rico e Filipinas para os Estados Unidos em 1898. Ainda que as conseqüências econômicas dessas perdas agora pareçam "pequenas", historiadores espanhóis podem Madrid, 1998.

26 NUNEZ, C. E. (Ed.). Debates and controversies in economic history.

27 DAVIS, L. E.; HUTTENBACK, R. A. Mammon and the pursuit of empire. The political economy of British imperialism. Cambridge, 1986.

28 BAIROCH, P. Economics and world history: myths and paradoxes. Hemel Hempstead, 1993.

29 PRADOS DE LA ESCOSURA; AMARAL, op. cit. 
sugerir que os ganhos da retenção do estado espanhol durante o século dezenove foram de importância comparável. ${ }^{30}$ No século vinte, as colônias espanholas incluíam alguns territórios limitados e alguns pobremente dotados no norte e na África central, mas a longa tradição de imperialismo da nação deixou uma maligna herança de protecionismo, nacionalismo e militarismo, que muito fizeram para prolongar o atraso da economia espanhola até os anos $60 . .^{31}$

As aspirações francesas para rivalizar com a Grã-Bretanha como uma potência imperial sofreram sérios contratempos nas guerras de 17561763 e 1793-1815. Depois disso, a França retomou terras e propriedades na África e Ásia e reconstruiu um império durante o século XIX, que durou até 1914, e que, em área, recursos naturais e população, perdia apenas para a Grã-Bretanha. ${ }^{32}$ Em termos de importância macroeconômica, o império francês pós-1815 pode ter contribuído ainda menos para o crescimento econômico nacional do que os impérios da Holanda e Portugal. ${ }^{33}$ Para a maioria das economias européias (particularmente Itália, Alemanha e Bélgica), que entraram na fase final do imperialismo, 1892-1903, mas também para outros estados que tinham retido territórios e populações bem pequenos e economicamente insignificantes no estrangeiro, as razões econômicas para qualquer envolvimento na colonização, durante o século dezenove, foram desprovidas de qualquer credibilidade posterior. ${ }^{34}$ Mesmo na época, as justificativas econômicas para o imperialismo pareciam espúrias simplesmente porque as parcelas de suas riquezas nacionais e populações, incluídas dentro dos limites dos recém-chegados impérios pobremente dotados, eram diminutas e qualquer perda potencial da renda nacional (emanando, mesmo no pior dos

30 FRAILE, P.; ESCRIBANO, A. The Spanish 1898 disaster: the drift towards national protectionism. Revista de Historia Económica, v. 16, p. 265-290, 1998; e PRADOS DE LA ESCOSURA, L. De imperio a nación cremimiento y atraso económico en España 1780-1830. Madrid, 1988.

31 CLARENCE-SMITH, W. G. The economic dynamics of Spanish colonialism in the nineteenth and twentieth centuries. Itinerario, v. 1, p. 71-88, 1991.

$32 \mathrm{O}$ império britânico era quase três vezes a área do império francês CLARK, op. cit., p. 23-28.

33 Brunschwig, Mythes et realités de l'imperialisme colonial français and Marseille, Empire colonial et capitalisme français. Nós somos gratos à David FIELDHOUSE pela referência a Marseille.

34 SNYDER, J. Myths of empire. Domestic politics and international ambition. Ithaca, 1991. 
cenários, do desimpedimento) poderia somente ter sido insignificante. ${ }^{35}$

As observações liberais de que a escala global do empreendimento imperial tinha sido bastante tangencial para o progresso econômico italiano, alemão, belga, espanhol, português e francês rendeu menos divisas para os holandeses e muito menos convicção para os casos britânicos, mesmo porque os ganhos materiais do império pareciam tangíveis para certas regiões, indústrias e para os grupos politicamente poderosos dentro daqueles reinos protestantes. Contudo, a importância econômica global dos impérios para o desenvolvimento dessas duas economias (realmente, para qualquer economia nacional) no longo prazo é melhor exposta por uma tabela de três colunas destinada a mostrar as escalas relativas (taxa) da mercadoria, do fator, e fluxos fiscais, dentro da economia doméstica, comparadas aos fluxos destinados e advindos da economia doméstica e seu império, que pode, por sua vez, ser contrastado com os fluxos entre o país e o resto da economia internacional. Em todo caso europeu, para o qual os dados estejam disponíveis, as interconexões através da exportação e importação de bens e serviços; da migração; da rede de fluxos de retornos dos investimentos estrangeiros (taxas, lucros e dividendos) e de outras conexões econômicas com o resto da economia mundial parecem incomensuravelmente mais importantes do que as ligações com os impérios. Mesmo para a Grã-Bretanha (a maior parte da economia européia estava interconectada com suas colônias e domínios ultramarinos), as relações econômicas com os países e territórios situados fora do império permaneceram mais importantes por uma grande margem, embora diminuindo, durante todo o século dezenove, 1815-1914. ${ }^{36}$

Este dado é relevante para a questão contrafactual de como e em que medida o desenvolvimento de economias específicas poderia ter mudado caso os estados europeus tivessem abandonado o controle político sobre suas colônias e dependências ultramarinas um pouco antes de 1914? Seqüências prováveis podem somente ser discutidas por historiadores especialistas com o conhecimento empírico requerido para se ocupar em conjecturas acerca dos caminhos e padrões das histórias econômicas nacionais (incluindo a colonial) que compreendem. Cenários pessimistas geram afirmações de que as colônias, uma vez consentidas suas independências,

35 Especialmente para a Itália, ver FEDERICO, G. Italy's late and unprofitable forays into empire. Revista de Historia Económica, v. 16, p. 377-402, 1998.

36 BAIROCH, P. Commerce extérieur et développement economique de l'Europe au XIXe siècle. Paris, 1976, é a melhor fonte para os dados europeus - ver NUNEZ, op. cit., p. $42-53$. 
poderiam ter caído em anarquia (uma percepção popular britânica acerca da retirada da Índia nos tempos vitorianos), de que a independência teria levado a tarifas mais elevadas em oposição às exportações das economias metropolitanas e de outras economias européias, de que as colônias separadas do domínio imperial somente poderiam ter se desenvolvido mais lentamente e, portanto, diminuído os níveis globais do comércio mundial. ${ }^{37}$

Alguma combinação de protecionismo com um crescimento mais lento parece ser uma conjectura mais realística a se buscar. Sobre esta suposição, um artigo paradigmático de Edelstein oferece estimativas para o declínio da renda nacional no curto prazo que poderiam contraditoriamente resultar na perda do controle político sobre o maior de todos os impérios europeus no estrangeiro - o império britânico. Suas estimativas ficam algo entre 1,6\% e $4,3 \%$ da renda nacional para 1870 e $4,9 \%$ a $6,5 \%$ para 1913 . Estas percentagens não são pequenas. Elas dependem, entretanto, de um conjunto específico de suposições sobre as tarifas, elasticidades da demanda e níveis de comércio que poderiam ter sido obtidos na ausência do domínio e da influência da GrãBretanha. Isto implica que esses números são superestimados porque os recursos usados para gerar exportações para as colônias supostamente têm custo de oportunidade zero e não são realocados - no modelo heurístico de Edelstein - para a sua segunda melhor alternativa. ${ }^{38}$ Ainda o exemplo da Espanha, após a perda de Cuba, Filipinas e Porto Rico, em 1898, mostra como os exportadores espanhóis se recuperaram rapidamente da repentina perda de mercados protegidos. ${ }^{39}$ Não existe razão para supor que as mais flexíveis e eficientes indústrias exportadoras da Grã-Bretanha, França e Alemanha (e mesmo Portugal) não teriam se ajustado ainda mais facilmente para uma "retirada em fases" do império ou de qualquer envolvimento com o empreendimento imperial durante a segunda metade do século XIX. ${ }^{40}$

Além do mais, para aquele período, é difícil encontrar exemplos de importações dos impérios europeus que não pudessem ser obtidos de fontes não imperiais a preços similares e (para as várias populações européias exploradas) mais baixos. Resumindo: as estimativas plausíveis para a rede de

37 A taxonomia destes argumentos é criticamente avaliada em CAIN, P. Was it worth having? The British Empire 1850-1950. Revista de Historia Económica, v. 16, p. 351-376, 1998.

38 EDELSTEIN, M. Imperialism: cost and benefit. In: FLOUD, R.; McCLOSKEY, D. (Ed.). The Economic History of Britain since 1700. Cambridge, 1994. v. 2, p. 197-216.

39 FRAILE, B. P. Industrialización y grupos de presión. La economía política de la protección en España. Madrid, 1991.

40 LAINS, P. A Econômica Portuguesa no século XIX. Lisboa, 1995. 
benefícios derivada do comércio da Grã-Bretanha e de outras economias com seus impérios sugerem que, após a metade do século, a rede de benefícios não poderia ter sido de outra maneira "pequena" - possivelmente tão baixos quanto $2 \%$ dos produtos nacionais brutos. Se este argumento pode ser sustentado para a Grã-Bretanha, segue-se que, durante a ordem liberal, os ganhos do comércio, advindos para as economias européias com um envolvimento bem mais limitado com os impérios (especialmente Itália, Alemanha e Bélgica), mas também Portugal, Espanha, França (e mesmo Holanda), poderiam ser representados como insignificantes e dispensáveis. ${ }^{41}$ Esta conclusão não impede variações interessantes através dos países, mudanças através do tempo ou negar que os mercados coloniais e as fontes de fornecimento pudessem ser importantes para algumas regiões européias (tais como a Castela rural), para algumas cidades (por exemplo, Barcelona e Amsterdã) e para indústrias especiais (tecidos de algodão catalãos, embarcações portuguesas e para construção de navios, e a produção de tecidos na Holanda), além do fato de que os ganhos advindos para a elite na Europa eram lucro da retenção dos impérios. ${ }^{42}$ Entretanto, a multiplicação dos exemplos locais não adiciona nenhuma importância macroeconômica.

Os proponentes do império (de então e agora) insistem, entretanto, que a difusão e a manutenção de uma ordem econômica internacional liberal dependiam da Pax Britannica, que, por sua vez, baseava-se na existência de um império britânico, e que os ganhos da Europa advindos do comércio (circulando a partir da sobrevivência daquele império) devem ter sido correspondentemente maiores. Eles reivindicam que as economias locais na Ásia, África e América do Sul não poderiam ter se tornado menos desenvolvidas e mais desconectadas do comércio internacional e da especialização na ausência de domínio colonial. ${ }^{43}$ Escrevendo após a descolonização, historiadores de outros continentes rejeitam essas visões como eurocêntricas e tendem a contradizer os cenários otimistas para o crescimento dos territórios descolonizados. ${ }^{44}$

41 O caso holandês é talvez quase análogo ao britânico - VAN DER ENG, P. Exploring exploitation: the Netherlands and colonial Indonesia, 1870-1939. Revista de Historia Económica, v. 16, p. 235-264, 1998.

42 DOYLE, W. Empires. Ithaca, 1986.

43 KENNEDY, P. The rise and fall of the great powers. London, 1988.

44 Ver BLAUT, J. The colonizers: model of the world. New York, 1993; e ADAS, M. (Ed.). Machines as the measure of men: science, technology and ideologies of western dominance. Ithaca, 1989. 
Outros elementos da balança de pagamentos incluem os fluxos de benefícios da migração da mão-de-obra e o investimento do capital nos impérios ultramarinos da Europa. Para a mão-de-obra, o império britânico agiu como uma válvula de segurança para os desempregados e como fonte de mobilidade ascendente para as ambiciosas e potencialmente incontroláveis celtas da Escócia e Irlanda. Como lugares de povoamento para a mão-deobra agrícola subempregada, as colônias italiana e espanhola tornaram-se lugares decepcionantes para os migrantes e a emigração em larga escala para Cuba somente ocorreu após aquela colônia ter se tornado independente..$^{45}$ O retorno dos fluxos de remessa parece ser maior para os migrantes empregados nos Estados Unidos e nas repúblicas independentes da América do Sul.

Duas características dos fluxos de fatores intercontinentais parecem ser razoavelmente claras. Primeiro, nem as colônias nem os domínios emergem das estatísticas britânicas, holandesas, francesas e italianas, particularmente, como destinos bem parecidos para emigrantes ou para o fluxo de poupanças alocados fora de suas economias domésticas por investidores britânicos e holandeses e muito menos pelos franceses, portugueses e espanhóis. ${ }^{46}$

Segundo, os dados reconhecidamente esparsos da história das empresas não proporcionam suporte às concepções leninistas de que por volta do final do século XIX o comércio imperial tinha se tornado necessário para protelar os retornos decrescentes do capital investido dentro da Europa Ocidental. ${ }^{47}$ Esses dados também não permitem assumir que os lucros [sic] "supernormais" destinados aos fundos existentes nas colônias mais seguras, onde, pelo menos em teoria, o poder colonial poderia ter sido substituído para assegurar taxas de lucros "espoliativas" para os capitalistas europeus. ${ }^{48}$ As tabulações para os estoques de capital britânicos, franceses e holandeses, investidos no estrangeiro no começo do século XX, não demonstram qualquer preferência marcada dos investidores europeus por localizações imperiais em relação às localizações estrangeiras. ${ }^{49} \mathrm{E}$, embora existam exemplos de lucros extremamente altos advindos para especulações privadas arriscadas em vários impérios europeus, modelos de taxas de retorno tanto do portifólio quanto/ou do investimento direto não parecem (sobre evidência reconhecidamente limitada) ter sido extraordinárias. ${ }^{50}$

45 SÁNCHEZ ALONSO, B. Las causas de la emigración española 18801930. Madrid, 1995.

46 BAINES, D. Emigration from Europe. Basingstoke, 1991.

47 BARRATT-BROWN, M. The economics of imperialism. 1974.

48 FIELDHOUSE, D. K. Economics and Empire. 1973.

49 DAVIS; HUTTENBACK, op. cit.

50 BAIROCH, 1993, op. cit. 
Neste ínterim, existe uma visão muito debatida de que os maciços escoamentos de fundos passíveis de investimento no resto do mundo (incluindo os impérios britânico e francês) operaram para atrasar os ajustes estruturais exigidos para o crescimento da indústria doméstica no longo prazo na Europa Ocidental. Em suma, agora existe uma suposição em relação ao Reino Unido e à França (e talvez também a Portugal e Holanda) de que parcelas significativas da formação do capital, público e privado, utilizadas para adquirir, desenvolver e defender as possessões imperiais no estrangeiro, podem ter gerado retornos subótimos e crescimento mais lento para algumas economias européias. Este é o motivo pelo qual a previsão de Hobson (feita no início de 1902) de que o investimento doméstico (ou no estrangeiro em países independentes dos impérios europeus) se tornaria uma alocação de capital superior para o crescimento econômico da nação parece inequivocamente clara para a Alemanha e a Itália, cujos patrimônios imperiais foram expropriados sem compensação das seguintes derrotas nas duas guerras mundiais do século XX. ${ }^{51}$ A propriedade espanhola em Cuba, Filipinas e Porto Rico não foi expropriada pelos Estados Unidos em 1898 e as perdas mensuráveis daquela derrota não parecem ter sido particularmente grandes. ${ }^{52}$

As folhas de balanço fiscal devem também ser examinadas minuciosamente. Após 1873, os impostos arrecadados para reter, expandir e defender as possessões ultramarinas britânicas, francesas, portuguesas e holandesas aumentaram a taxas que, preocupando governos, fortaleceram o argumento dos críticos liberais de que os custos dos impérios para os contribuintes metropolitanos podiam ter excedido os benefícios que eles receberam por nítidas e crescentes margens. ${ }^{53}$ Talvez (e apesar de uma abundância de registros orçamentários), para a maioria dos estados, as "cargas fiscais" do império não eram simples de se definir, tratáveis para mensuração e certamente não eram fáceis para serem relacionadas aos fluxos compensatórios dos benefícios econômicos, estratégicos, físicos e de outros benefícios do império destinados às economias e sociedades metropolitanas durante o tempo.

51 HOBSON, C. K. Imperialism. Ann Arbor, 1967; FEDERICO, op. cit.; e KENNEDY, W. P. Industrial structure, capital markets and the origins of British economic decline. Cambridge, 1987.

52 FRAILE; ESCRIBANO, op. cit., p. 265-90; e MALUQUER DE MOTE, J. El mercado colonial antillano en el siglo XIX. In: NADAL, J.; TORELLA, G. (Ed.). Agricultura, comercio colonial y crecimiento económico en la España contemporánea. Barcelona, 1974. p. 64-73.

53 THORNTON, A. K. The imperial idea and its enemies. 1959. 
As despesas anuais, feitas pelos governos metropolitanos em nome de seus impérios, podem ser comumente estimadas. Consideráveis parcelas do gasto público para este propósito consistiam dos custos naval e militar da conquista imperial, pacificação e, por conseguinte, para a lei e a ordem e para a defesa das colônias e domínios das ameaças de ataque do inimigo. Os custos iniciais, ou threshold, de se adquirir território, bases, populações e recursos no estrangeiro, aparecem comumente nos dados fiscais nacionais e para todas as despesas com guerras (por exemplo, os custos de uma guerra argelina, etíope ou maori). A pacificação poderia, entretanto, levar muitos anos e os custos de oportunidade do potencial humano e de outros recursos "consumidos" na conquista são normalmente considerados como ocorrências passadas pelos governos propensos a fixar limites em função dos registros passados de devassidão. Uma vez que os gastos da conquista foram financiados por empréstimos, eles foram concebidos pela contabilidade oficial como custos "irrecuperáveis" e normalmente eram perdidos de vista. ${ }^{54}$ Isto à exceção do império britânico, onde a presença, durante toda a era liberal, de uma extraordinariamente grande dívida nacional aliado a um significativo volume do serviço desta dívida (absorvendo 56\% da arrecadação na década de vinte do século XVIII), serve para lembrar aos historiadores que a aquisição, a extensão e a retenção do império britânico tinham sido altamente custosas. ${ }^{55}$ Embora suposições aceitáveis possam ser feitas com o propósito de se estimar as alocações governamentais para seus impérios, os problemas de se reclassificar os gastos militar e naval feitos pelos estados europeus em despesas anuais "requeridas" para a defesa das metrópoles e de seu comércio no estrangeiro, por um lado, e gastos contraídos para a proteção das possessões, localizadas além dos limites dos estados nacionais, por outro lado, não são facilmente superados. O que parece claro (com as possíveis exceções da Índia e Indonésia) é que as economias e populações de quase todas as colônias e domínios europeus contribuíram muito pouco para os custos de suas próprias defesas da agressão externa ou da insurreição interna. Além disso, em alguns casos (por exemplo, Itália e Portugal), um exame minucioso das contas orçamentárias revela que os impostos arrecadados das populações e economias nativas cobriam somente frações de todos os gastos públicos

54 HOBSON, J. A. The wealth of states. Cambridge, 1997. Apresenta uma excelente discussão destes problemas.

55 O'BRIEN, P. K. The security of the realm and the growth of the economy 1688-1914. In: CLARKE, P.; TREBILCOCK, C. (Ed.). Understanding decline. Cambridge, 1997. p. 61-72. 
contraídos para a administração civil e para o investimento público em facilidades infra-estruturais e em serviços requeridos para seus governos. ${ }^{56}$

Os gastos dos governos europeus em tropas, marinheiros, armas, equipamento, fortificações, bases, navios de guerra etc., podiam, em teoria, ser divisíveis nas proporções exigidas para a defesa da metrópole e de seu comércio, por um lado, e alocações para a proteção de seus domínios e colônias ultramarinas, por outro lado. Na prática, essa distinção tornou-se pouco nítida nas percepções dos reis, estadistas, almirantes e generais responsáveis pelo planejamento estratégico. Historiadores dos impérios, Romanov e Habsburg argumentam que esta distinção não tem real significado ou sentido histórico para os impérios no exterior.

Em 1936, Grover Clark produziu alguns dados destinados a mostrar que os gastos anuais dos governos britânico, francês, italiano, alemão e japonês na formação de capital nas suas colônias e com os exércitos e marinhas, exigidos para a proteção do comércio imperial, excederam por uma ampla margem qualquer ganho possível do comércio imperial. Por exemplo, em um dos seus cálculos, Clark assumiu que os gastos do governo francês na capacidade militar e naval exigida para proteger o comércio com seu império seriam proporcionais à parcela do total do comércio francês conduzido com as colônias entre 1894 e 1934. Resumindo, ele adicionou os gastos diretos do governo francês com despesas civis nas colônias. Suas figuras mostram que o total das despesas, financiado pelos contribuintes, somou $21 \%$ do valor bruto do total do comércio colonial. ${ }^{57}$ Outros historiadores complicaram e ampliaram a folha de balanço fiscal ao argumentar que as contribuições "voluntárias" do potencial humano e de outros recursos feitos pelos domínios e colônias para a defesa da França e GrãBretanha, no curso de quatro anos de guerra contra a Alemanha e as Potências Centrais, 1914-1918, representaram algum reconhecimento de que a metrópole havia carregado o fardo da defesa imperial nos tempos de paz e não poderia arcar com todos os custos envolvidos no combate aos exércitos e marinhas alemãs nos tempos de guerra. ${ }^{58}$

A lealdade às terras natais amadureceu em territórios inestimáveis, mas isto não implica que os impérios carregassem parcelas

56 LAINS, P. An account of the Portuguese African empire. Revista de Historia Económica, v. 16, p. 235-264, 1998; e FEDERICO, op. cit., p. 352-376.

57 CLARK, op. cit.

58 OFFER, A. The British empire: a waste of money? Econ. Hist. Rev., n. 45 , p. $215-238,1993$. 
desproporcionais dos custos contraídos para derrotar o Kaisereich, ou que as contribuições de guerra das colônias e domínios fossem, de algum modo (e em termos econômicos claros), compensados pelos níveis mais altos dos impostos impingidos aos cidadãos britânicos, franceses, holandeses e a outros cidadãos para a defesa imperial por muitas décadas antes de 1914. Além disso, a persistente dificuldade de se fazer uma clara distinção entre a defesa das pátrias européias e a proteção dos patrimônios imperiais no estrangeiro levou a um contexto político e cultural em que, por várias décadas antes da Grande Guerra, o planejamento estratégico da Grã-Bretanha permaneceu muito desprendido do envolvimento com o equilíbrio de poder no continente europeu. Os estadistas britânicos falharam em forjar alianças diplomáticas e em construir forças militares exigidas para deter a agressão alemã. Acerca desta interminável contabilidade histórica, as preocupações britânicas (também francesas e alemãs) com o império no estrangeiro podem ser representadas como fracassos da imaginação liberal, que se somaram ao erro estratégico mais custoso na história diplomática européia. ${ }^{59}$

Esses argumentos continuarão indefinidamente. Neste ínterim, é certamente sem sentido negar que a extensão e a defesa dos impérios europeus contra as ameaças de agressão externa e de subversão interna custaram muito aos contribuintes metropolitanos e que, por toda a Europa, tais cargas fiscais aumentaram seguindo a unificação da Alemanha em 1871. Além disso, a incidência de tais impostos não foi calibrada para cair sobre as rendas dos contribuintes, que tiraram a maior parte dos ganhos materiais dos gastos estatais nas possessões ultramarinas. De todo modo, os custos fiscais dos impérios europeus não são facilmente definidos e mensurados porque os bens públicos, como defesa e diplomacia, não podem ser facilmente acomodados numa estrutura de análise custo-benefício. Parece haver vários pontos obscuros, muitas externalidades impagáveis e ramificações estratégicas que são muito difundidas pelas categorias para conter proposições mensuráveis, como distinto de plausível, acerca das alocações dos impostos metropolitanos com o propósito de adquirir e manter impérios no estrangeiro.

Os recursos certamente poderiam ser consumidos em conflitos imperiais fúteis e desperdiçados em incidentes diplomáticos não lucrativos (por exemplo, as guerras entre os Estados Unidos e a Espanha em 1898 e entre a Rússia e o Japão em 1904, como também a crise marroquina de 1905 e 1911). ${ }^{60}$ Ainda antes de 1914, o volume dos recursos alocados ano

59 BECKETT, J.; GOOCH, J. (Ed.). Politicians and defence: studies in the formulation of British defence policy. Manchester, 1981.

60 KEYLOR, W. R. The twentieth century world. Oxford, 1984. 
após ano pelos governos europeus, especificamente e claramente para a manutenção e defesa dos impérios, não poderia ter se constituído em outra coisa senão "pequenas" parcelas de seus produtos nacionais. Representadas na mais desfavorável luz como oportunidades perdidas para investimentos dentro das economias metropolitanas, as parcelas da formação do capital doméstico hipoteticamente abandonadas podiam ser descritas como sendo relativamente grandes no caso britânico, mas muito menores para outras potências européias. ${ }^{61}$

Resumindo: entre 1846-1914, as potências européias ampliaram, mantiveram e defenderam impérios no estrangeiro a "preços muito baixos". $\mathrm{Na}$ época, os radicais sugeriram, (provavelmente corretamente) que uma retirada planejada das regras formais não teria resultado na diminuição dos ganhos do comércio, menores retornos do investimento no estrangeiro, ou qualquer fechamento das oportunidades para a emigração. Os historiadores agora reconhecem que algumas (mas talvez não acentuadas) reduções nas cargas dos impostos poderiam ter sido seguidas da descolonização. Num mundo de livre comércio, de integração dos mercados, de fatores e de arranjos estáveis para os pagamentos internacionais, na melhor das hipóteses, os impérios haviam se tornado economicamente irrelevantes para o desenvolvimento da Europa no longo prazo. Paradoxalmente, os impérios estavam crescendo e a interpretação agrária da Primeira Grande Guerra, elaborada recentemente, fornece uma explicação estrutural para o ocorrido. A crescente independência das maiores economias européias, em relação aos alimentos importados e às matérias-primas, tornou suas populações vulneráveis ao bloqueio e inclinou seus governos a manter, e mesmo fortalecer, laços com os impérios e também a desafiar, pela construção de navios rivais europeus, americanos e japoneses, ${ }^{62}$ a longa hegemonia britânica no mar. As disputas coloniais certamente tiveram um papel na derrocada em direção à mais custosa guerra da história de nossos continentes, basicamente ao obstruir e ofuscar a formulação de políticas diplomáticas e estratégicas exigidas para manter um equilíbrio de poder efetivo na Europa.

61 HOBSON, 1997, op. cit.

62 WILLIAMSON, G. W. Globalization convergence and history. Jnl. Econ. Hist., n. 56, p. 277-306, 1996; e OFFER, A. The first world war: an agrarian interpretation. Oxford, 1989. 


\section{GUERRA GLOBAL, NEOMERCANTILISMO E A REINTEGRAÇÃO DOS IMPÉRIOS EUROPEUS DE 1914 AO TRATADO DE ROMA}

A primeira guerra mundial, que efetivamente levou a expansão européia além-mar ao fim, pode ser representada como a terceira conjuntura significativa (após 1497-92 e 1789-1825) na história do imperialismo europeu. Quatro anos de destruição terminaram com os Tratados de Versailles e Sevres, o qual (como o Tratado de Viena um século atrás) redistribuiu as províncias e colônias das nações derrotadas (nesse momento, Alemanha e Turquia) entre os vitoriosos França, Grã-Bretanha e Itália; desmembrou o império de Hamburgo e criou as repúblicas independentes da Polônia, Finlândia, Latia, Lituânia e Estônia, dos territórios do império Romano.

Em 1919, num momento em que a ordem econômica internacional começou a se distanciar rapidamente dos arranjos superficialmente regulados de comércio de bens, movimento de capital, difusão de tecnologia, migração de força de trabalho e transferência de pagamentos através das fronteiras que tinham caracterizado o comércio internacional por várias décadas antes de 1914, estados europeus vitoriosos assumiram a responsabilidade por grandes impérios e dependências. É claro que tendências rumo a um novo protecionismo podem ser observadas nas leis que afetam o comércio e os pagamentos internacionais promulgados por vários governos entre 1876 e 1914. Em quase todos os países (inclusive na Grã-Bretanha) lobbies e ideologias atuaram para enfraquecer a ordem liberal que havia promovido maior integração e relações econômicas internacionais mais eficientes por três décadas depois de 1846. Embora o livre comércio tivesse existido apenas como uma "utopia não experimentada" e restrições nos fluxos de mercadorias, serviços, capital, trabalho e tecnologia em todo o mundo certamente intensificadas durante o último quarto do século XIX, tarifas em geral e outras formas de controle se mantiveram limitadas o suficiente para permitir uma contínua expansão do comércio internacional e da mobilidade de fatores até a eclosão da primeira guerra, em 1914. Na verdade, os anos 18991913 testemunharam uma recuperação no crescimento do comércio, fluxo de capital e migração, superado apenas em escala e intensidade pelo famoso e longo boom entre 1948 e 1973, que constituiu o pano de fundo para a descolonização após a segunda guerra mundial. ${ }^{63}$ Antes da Grande Guerra, as

63 O'BRIEN, P. K. Intercontinental trade and the development of the third world since the industrial revolution. Jnl. World Hist., n. 8, p. 75-133, 1997. 
oportunidades para comercializar e investir na economia mundial como um todo continuaram sendo relativamente ilimitadas e os argumentos para uma integração imperial mais intensa, que emergiu antes mesmo do final do século XIX, não pareciam atrativos o suficiente para alterar radicalmente o rumo das políticas comerciais européias. Por mais de uma década, após o fim do século, os atrativos do império pareciam mais atávicos e xenófobos do que materiais. ${ }^{64}$

Infelizmente, a Grande Guerra pressionou quase todas as economias européias em direção à autarquia, restringiu as fronteiras políticas dos mercados de produtos e de fatores e reintroduziu sérias considerações militares no discurso sobre os custos e benefícios dos impérios. Isso ocorreu porque, no começo e durante a guerra, as exportações e a demanda por alimentos, matériaprima e equipamento militar, o recrutamento de homens de fontes seguras e protegidas, proporcionadas por colônias, tinham se tornado uma "necessidade estratégica".

As contribuições coloniais para os esforços de guerra das metrópoles constituíram não mais do que uma fração do total de recursos alocados pelas alianças vitoriosas da Grã-Bretanha, Rússia, América, França e outras potências para defender a Alemanha e os poderes centrais na primeira Grande Guerra. Entretanto, uma guerra naquelas dimensões não é facilmente entendida sem uma avaliação econômica do império. Pelo menos o curso, os custos e as consequiências da Grande Guerra alteraram as percepções na Europa e mudaram os parâmetros com os quais a economia dos impérios começou a ser discutida. Antes de mais nada, o suporte popular e ideológico para fortalecer as conexões imperiais se tornou mais significativo como resultado das ligações forjadas durante os quatro ou cinco anos de sacrifício compartilhado para a defesa das pátrias-mãe. Ligações com as nações amigas e um profundo senso de responsabilidade para com "nosso" povo e territórios além-mar se aprofundaram durante o período da guerra. Em segundo lugar, a guerra desmontou o comércio e os fluxos de fator intra-europeus, promoveu um movimento em direção à autarquia nos países e levou a uma dependência em maior grau do comércio e investimento imperiais entre as nações européias (Grã-Bretanha, França, Bélgica, Holanda, Itália, Espanha e Portugal), as quais podiam optar pelo comércio - no contexto da segurança política, proteção, regulação comercial e arranjos monetários, proporcionados por redes coloniais de dependência e domínios no exterior. Em terceiro lugar, o enorme custo, para as economias européias, de mobilização para a guerra e de desmobilização para a paz, a maciça destruição do estoque de capital e a perda de gerações de

64 BETTS, R. F. Europe overseas: phases of imperialism. New York, 1968. 
trabalhadores mortos e feridos resultaram em algo equivalente a entre quatro e cinco vezes o produto nacional da Europa em 1913. Mesmo seguindo os pressupostos mais favoráveis sobre os prospectos para um crescimento renovado depois da guerra, perdas naquela magnitude levariam uma geração inteira para serem compensadas. Taxas mais elevadas de recuperação freqüentemente dependiam da importação de bens de capital, matéria-prima e trabalhadores qualificados, os quais tornaram o comércio externo e/ou estruturas produtivas capazes de emprestar nos mercados financeiros internacionais numa dimensão maior do que tinham sido antes da Grande Guerra.

Infelizmente, esse dispendioso conflito não apenas devastou os estoques de capital físico e humano, mas deslocou seriamente o sistema internacional de comércio e pagamentos, dos quais haviam dependido o investimento e crescimento futuro. Por muitos anos depois de 1918, as relações econômicas internacionais continuaram a ser afetadas pelas conseqüências do Tratado de Versailles, pelos controles exercidos pelo Estado sobre a condução da guerra e, acima de tudo, pelas heranças malignas das estratégias financeiras, perseguidas pelos governos para custear maciços gastos de suas forças armadas entre 1914 e 1918. Embora os impostos per capita tivessem mais do que dobrado em termos reais, os estados europeus tinham emprestado a maior parte do dinheiro necessário para a guerra pelos seus próprios bancos. Portanto, o problema de como reduzir a inflação e de como trazer os níveis dos preços nacionais e o papel moeda de volta a algum tipo de relação sustentável entre eles emergiu como a maior preocupação dos homens de estado e dos diretores de bancos centrais nos anos do pós-guerra. ${ }^{65}$ Suas dificuldades eram compostas de problemas conjugados das dívidas entre nações aliadas e das reparações Alemãs. Desacordos políticos sobre o status dessas dívidas levaram a recriminações entre antigos aliados (além de um profundo rancor na Alemanha), o que complicou a já difícil tarefa de reconstruir um sistema internacional de comércio e pagamentos. ${ }^{66}$

A guerra também reforçou as tendências ao protecionismo latente, também evidente antes de 1914. Por exemplo, o Tratado de Versailles proporcionou o desmembramento de três impérios multinacionais de livre

65 FEINSTEIN, C. F. (Ed.). Banking, currency and finance in Europe. Oxford, 1995.

66 TRACHTENBERG, M. Reparations in world politics: France and European economic diplomacy. New York, 1980. 
comércio e a criação de novos estados na Europa com controle autônomo sobre tarifas e comércio exterior. Separados por barreiras e custos de transportes exorbitantes para importação de manufaturas, uma longa lista de países embarcou em programas de substituição acelerada de importações. Ao fim das hostilidades, quando governos nacionalistas encontraram suas indústrias nascentes ameaçadas por uma renovada concorrência internacional, levantaram barreiras tarifárias. A auto-suficiência em alimentos e matéria-prima, a qual também se tornou uma questão de segurança nacional em tempos de guerra, provou ser politicamente difícil de ser revertida quando a paz retornasse ${ }^{67}$

Enquanto seria impossível predizer como a ordem internacional poderia ter se desenvolvido sem a catástrofe da Grande Guerra, do ponto de vista das vantagens do longo boom na economia mundial, de 1899 a 1914, seria impossível não ser otimista quanto às perspectivas futuras. Taxas de crescimento da produção e comércio exterior, da migração e fluxos de capital através das fronteiras, atingiram níveis recordes. As economias européias pareciam estar se ajustando à realidade da concorrência internacional, incluindo o surgimento do Japão e, mais importante, o surgimento dos Estados Unidos, o qual, na última década do século XIX, tinha emergido como a potência hegemônica industrial do século XX.

O declínio relativo da Europa se tornou mais um problema depois de uma guerra que havia presenciado a maciça destruição de capital físico e humano, a exaustão e pilhagem das economias alemã e austríaca e o caos econômico gerado pela revolução russa. Enquanto isso, a escassez dos tempos de guerra havia promovido um crescimento mais rápido de várias novas economias industriais: notadamente Estados Unidos, mas também Canadá e Japão, além de várias economias da América Latina. ${ }^{68}$ Em vista dos saltos descontínuos na posição competitiva da indústria americana, no período de desordem nas relações econômicas internacionais, elevados níveis de proteção e recuperação da mais dispendiosa guerra desde Napoleão provaram ser muito difícil para o capitalismo e liberalismo europeus. Nos anos 30, o sistema havia sucumbido à depressão, comunismo, fascismo e à implementação de programas de integração imperial.

Tais programas, concebidos durante a guerra e evoluídos ao longo dos anos 20, tornaram-se prioridade na agenda política no início da Grande

67 CAPIE, F. Tariffs and growth: some illustrations from the world economy 1850-1940. Manchester, 1994.

68 FEISTEIN; TEMIN; TONIOLO (Ed.). The European economy between the wars. 
Depressão, apresentando falhas de homens de estado e diretores de bancos centrais para reconstruir uma ordem econômica internacional livre de inflação, com taxas estáveis de câmbio, níveis moderados de proteção e interferência mínima dos governos com fluxos de mercadorias, capital e trabalho através das fronteiras. Portanto, para várias economias européias (Grã-Bretanha, França, Portugal, Espanha e Itália), a integração imperial parecia ser um substituto viável para uma ordem internacional mais aberta, num momento em que o crescimento do comércio mundial tinha diminuído e o comércio entre países tinha afetado graus de risco e instabilidade nunca vistos desde a era mercantilista. ${ }^{69}$

Pela terceira vez (ou talvez a quarta em trinta anos de conflito em torno de religião, 1618-1648, incluído nessa cronologia), outra guerra mundial e suas conseqüências durante os anos 40 causaram um rápido encerramento da longa história das relações políticas entre os estados europeus, suas colônias e seus patrimônios e posses no exterior. A maior parte das mudanças na natureza e escala dessas conexões, que proliferaram após a segunda guerra mundial (1939-1945) e o período de recuperação no pós-guerra, refletiu a experiência da primeira guerra e suas consequiências. ${ }^{70}$

Por exemplo, Espanha e Portugal haviam permanecido neutros durante ambas as guerras. Mas durante a grande depressão dos anos 30 e durante o período de conflitos e de recuperação dos seus efeitos destrutivos que atingiram a economia internacional nos anos 40 , a dependência daqueles países de suas colônias como mercados e fontes supridoras de alimentos, matéria-prima, minerais e combustível, aumentou tão significativamente como em qualquer outro país da Europa ${ }^{71}$ Embora as conexões da Espanha com seu império fossem muito menores do que as de Portugal, a rebelião militar de Franco, que mergulhou a Espanha em guerra civil e isolamento, foi lançada a partir das colônias espanholas na África, as quais também proporcionaram as divisas monetárias para financiá-la durante seu estágio inicial. $^{72}$

Entre 1939 e 1945, os exércitos e os recursos de todo o império britânico foram mais uma vez mobilizados para derrotar as forças armadas da Alemanha, Japão, Áustria, Itália e outras potências do eixo nos campos de batalha, espaço aéreo e linhas marítimas na Europa, Ásia, África e

69 ZIEBERG, G. World economy and world politics. Oxford, 1990.

70 VAN DER WEE, H. Prosperity and upheaval: the world economy, 194880. 1986.

71 LAINS, 1998, op. cit.

72 BALFOUR, S. The end of the Spanish empire, 1898-1923. 1997. 
Américas. Tal ajuda, em tempos de grave ameaça nacional, sempre havia sido profundamente bem-vinda, mas sua magnitude ainda não havia sido mensurada de tal forma que desse uma idéia precisa de seu significado econômico. Da mesma forma, a herança e a memória, freqüentemente reavivada, da contribuição do império à vitória nas duas guerras mundiais, à estabilização da economia doméstica durante períodos de instabilidade e depressão entre as guerras e às recuperações da Grã-Bretanha após 1918 e após 1945, tornaramse partes onipresentes na cultura política que moldou as políticas comerciais, fiscal e monetária implementadas por sucessivos governos britânicos no período entreguerras e por várias décadas após $1945 .{ }^{73}$

Preferências imperiais, subsídios fiscais e isenções, formação das áreas da libra esterlina, tratados comerciais, arranjos bilaterais, programas de ajuda e desenvolvimento e acordos de troca se tornaram muito mais fortes e desenvolvidos no contexto de leis, regras e regulações imperiais mais restritas, com as quais a economia britânica operou após $1914 .{ }^{74}$

Respondendo de forma mais ou menos similar às mudanças na correlação de forças, às crises prolongadas, à ordem econômica internacional liberal e à existência de um poder industrial no continente da América do Norte, os governos da França, Bélgica, Portugal, Espanha e Itália também envolveram suas economias em tratados, regulações, acordos e blocos de regulação e monetários concebidos para sustentar integração imperial. ${ }^{75}$ Para algumas sociedades do continente europeu, notadamente França e Bélgica, a herança do império e o papel positivo exercido por suas colônias na derrota da Alemanha foi incorporado pelo sentimento popular em favor de "France outre mer". ${ }^{76}$ Em outros países, especialmente Grã-Bretanha (mas também a Itália sob Mussolini), as pretensões de atingir um status de grande potência dependiam da posse de um império ou de tradições e influências necessárias para perfilar um grupo de países que haviam sido colônias anteriormente. ${ }^{77}$ Por longos períodos do século XX, a política e a cultura do imperialismo reforçaram as pressões estratégicas e econômicas sobre os governos europeus para extrair mais de seus impérios.

1993.

73 CAIN, P.; HOPKINS, A. G. British imperialism crisis and deconstruction.

74 ALFORD, B. Britain in the world economy since 1880. Harlow, 1996.

75 FIELDHOUSE, D. K. Colonial empires since the eighteenth century. New York, 1967.

76 BETTS, R. F. France and decolonization. 1991.

77 FEDERICO, op. cit. 
Enquanto isso, o discurso de Cobdenite em favor do livre mercado e por desengajamento dos impérios enfraqueceu, embora não tenha desaparecido. Na realidade, antipatias pelo império, incorporadas no liberalismo clássico, foram complementadas pelas doutrinas socialistas, contendo suporte aos movimentos de independência colonial que emergiam na Ásia, África e no Caribe, no período entreguerras. Entretanto, o clima de hostilidade e desconfiança entre os países após 1914, o estado depressivo do comércio mundial e a tendência quase universal em direção à regulação política das relações econômicas internacionais contribuíram articuladamente para que as elites concebessem os impérios como soluções para seus problemas estratégicos e dificuldades econômicas domésticas. ${ }^{78}$ As recomendações de Cobdenite para o desengajamento dos impérios se tornaram tão remotas dos centros de poder quanto os sermões dos ativistas de esquerda pregando a emancipação colonial.

Para cada conjunto nacional de informações disponível, relacionado ao comércio de mercadorias, à compra e venda de serviços, aos fluxos de investimentos e força de trabalho para o exterior (da mesma forma que os levantamentos nacionais sobre o funcionamento dos sistemas monetários e de pagamentos nacionais), são inconfundíveis as evidências de uma maior integração entre economias metropolitanas e suas colônias e povos (excolônias) estrangeiros integrados. É claro que os graus de integração variavam, sendo menos óbvios nos casos da Holanda e França. ${ }^{79}$ Entretanto, na maior parte dos indicadores, as tendências em direção à integração imperial (a qual começou durante a primeira guerra mundial) se intensificaram durante a grande depressão dos anos 30. Eles alcançaram o apogeu durante e por volta de dez anos após a segunda guerra, quando uma economia internacional deslocada e uma severa escassez de divisas (especialmente dólares) aumentou a dependência das potências européias em relação às suas colônias e ex-colônias.

Portanto, durante mais de quatro décadas de guerra, neomercantilismo e instabilidade, 1914-1958, os estados europeus se voltaram (talvez no longo curso da história deveria-se dizer retornaram) às suas colônias e domínios para obter ajuda estratégica e assistência econômica. Será que a disponibilidade de opções imperiais fáceis desviaram a atenção dos homens

78 ROGOWSKI, R. Commerce and coalitions: how trade effects domestic political arrangements. Princeton, 1989.

79 VAN DER ENG, op. cit., p. 291-321; e FITZGERALD, E. P. Did France's colonial empire make economic sense? A perspective from the postwar decade 1946-56. Jnl. Econ. Hist., v. 48, p. 373-385, 1988. 
de estado das dificuldades de reconstruir uma ordem internacional? Provavelmente. Entretanto, contribuições dos impérios para a segurança das metrópoles e para a estabilidade e crescimento de suas economias foram concebidas (e têm sido abordadas por muitos historiadores desde então) como positivas e significativas. Por longos períodos do século XX, as prescrições de Cobdenite e dos socialistas contra os impérios se tornaram crescentemente irreais. ${ }^{80}$

Apenas como um prelúdio da descolonização européia, a reintegração imperial pode ser incluída na matriz das contas nacionais apenas como uma segunda melhor solução para os problemas criados pela guerra e para o deslocamento da ordem liberal internacional. Dessa forma, o comércio e fluxos de investimento intra-imperial, conduzidos dentro do sistema preferencial de tarifas, blocos de moedas, negociações multilaterais e arranjos políticos, os quais prevaleceram em torno de 40 anos depois de 1914, podem ser entendidos como soluções subótimas, comparadas a um livre comércio internacional. Tais sistemas certamente geraram ganhos em termos de troca e especialização. Mais do que isso, o comércio imperial representou um avanço relativo à alternativa dominante do período tendências nacionais e regionais rumo à autarquia - particularmente quando as colônias podiam ser induzidas (ou mesmo forçadas) pelos governos metropolitanos a participar do comércio em mercados mais amplos. Entretanto, os benefícios oriundos da criação de comércio dentro dos blocos comerciais imperiais provavelmente não excederam os custos de desvio de comércio, simplesmente porque as disparidades de poder político entre as autoridades metropolitanas e locais (incluídas nos impérios europeus ou eximpérios - os commonwealths) normalmente tentaram promover uma complementaridade entre as economias, limitaram a concorrência e mantiveram vantagens comparativas nacionais e regionais dentro dos padrões históricos e amplamente estáticos da especialização. Freqüentemente, os sistemas de preferência imperial operavam para dar sustentação à tradicional indústria alimentar européia e a segmentos de sua agricultura que eram ineficientes, comparados aos seus competidores de outros países. Ao mesmo tempo, algumas populações metropolitanas (e especialmente famílias francesas e portuguesas) pagavam preços relativamente altos pelo privilégio de consumir alimentos e matéria-prima oriundos de suas colônias. Os impérios normalmente suportavam padrões divergentes embora complementares de comércio inter-

80 MAIER, C. In search of stability: explorations in historical political economy. Cambridge, 1987. 
regional. ${ }^{81}$ Independente da forma como foram politicamente montados, como arranjos institucionais para a especialização, os impérios não puderam ser tão eficientes para promover crescimento e desenvolvimento na Europa como as uniões aduaneiras e áreas de livre comércio, as quais sustentaram competição e conduziram à convergência e padrões diferentes de especialização entre economias que são geograficamente contíguas, homogêneas e não tão diferentes em seus níveis estruturais de desenvolvimento industrial. ${ }^{82}$

Infelizmente, a pesquisa sobre a história dos negócios no século XX não tem ainda produzido amostras de estudos de caso, necessários para testar a proposição de que a realocação de investimento metropolitano para os países integrantes do império (comparado a doméstico e estrangeiro) pode ter gerado retornos subótimos para as economias européias. Taxas extraordinárias de lucro foram certamente obtidas por companhias britânicas, francesas, holandesas, belgas, espanholas e portuguesas, engajadas na prospecção de minérios e óleo cru. Lavouras produzindo culturas comerciais são outro setor com os quais os investidores europeus obtiveram lucros acima do normal. Exemplos de contratos e direitos de concessão, ligados à exploração de terras e minas, favoráveis, através dos quais as companhias européias operaram por várias décadas depois de 1914, freqüentemente resultaram em um contexto político de governo colonial e poder de mandato. Entretanto, outras companhias e investidores europeus, além das americanas, suíças, alemãs, sem os mesmos privilégios (e custos!), envolveram-se nas regras formais do império. Há ainda pouca evidência de que o poder colonial tenha sido direta e sistematicamente usado para garantir "rendas econômicas" para o capital metropolitano localizado nas colônias, protetorados e dependências européias. Na ausência das estatísticas necessárias, taxas de lucro obtidas por tais capitais podem ainda, de forma plausível, ser representadas como "normais" para investimentos de risco comparável localizados no interior de países europeus e/ou estrangeiros. ${ }^{83}$

Mais do que isso, uma vez que os movimentos coloniais por emancipação emergiram como sérias ameaças às regras de domínio colonial e as capacidades política e militar dos estados europeus de resistência haviam sido fragilizadas pelas antipatias democráticas pelos impérios, os

81 JOHNS, R. A. Colonial trade and international trade. 1988.

82 CRAFTS, N. F.; TONIOLO, G. (Ed.). Economic growth in Europe since 1945. Cambridge, 1996.

83 REYNOLDS, L. G. Economic growth in the third world, 1850-1980. 1985. 
riscos (na verdade as perdas registradas) de perda de capital europeu devido à violência e expropriação aumentaram enormemente. ${ }^{84} \mathrm{Em}$ meados do século $\mathrm{XX}$, haviam poucos locais onde os capitalistas europeus ainda podiam contar com as autoridades coloniais para ajudá-los a obter taxas de lucro "espoliativas". Com a descolonização a caminho, os governos europeus concentraram-se (normalmente sem grande sucesso) em garantir compensações pela perda de patrimônios fixos através das transferências e nacionalizações de propriedade, que ocorreram em quase todas as colônias após o fim dos impérios. Quaisquer que fossem os benefícios psicológicos e estratégicos, existem poucas dúvidas de que os custos ficais de manter o domínio colonial aumentaram dramaticamente durante e depois da primeira guerra mundial. $\mathrm{O}$ fardo imposto aos pagadores de impostos para cobrir os gastos dos estados europeus, referentes à defesa externa, à manutenção da ordem e ao desenvolvimento econômico e social de suas colônias e protetorados, aumentou crescentemente. $^{85}$

Adicionalmente, tais gastos não podiam ser facilmente compartilhados. Os domínios britânicos, para citar um exemplo, continuaram a resistir a pressões para contribuir com uma parcela maior dos custos de defesa imperial. Levando em consideração os sacrifícios feitos durante a primeira guerra mundial, podendo fazê-los novamente, Londres não alimentou muito aquelas pressões. Enquanto isso, o fracasso do Tratado de Versailles em restaurar o equilíbrio de forças na Europa e as intenções predatórias da Alemanha, Itália e Japão em relação aos impérios britânico, francês, holandês e português na África e Ásia se tornaram previsíveis e mantiveram os gastos para conter agressões externas num patamar bastante elevado. Planejadores estratégicos britânicos e franceses ficaram mais alertas (do que haviam estado antes de 1914) sobre as tensões envolvendo a defesa de seus países na Europa e a proteção de suas posses além-mar, contra os ataques de tais potenciais oponentes como a Alemanha e Itália, na África, e o Japão, na Ásia e Pacífico. ${ }^{86}$

Ao mesmo tempo e estimuladas pelos ideais Wilsonianos de autodeterminação, pelas teorias marxistas de exploração e pelas velhas idéias européias de democracia, os movimentos pela emancipação colonial começaram a elevar os custos de manutenção interna da ordem, particularmente

84 LIPSON, C., Standing guard: protecting foreign capital in the nineteenth and twentieth centuries. Berkeley, 1985.

85 KOPCHAN, C. A. The vulnerability of empire. 1994.

86 FRENCH, D. The British way of warfare, 1688-2000. 1990. 
na Índia e na África. Após a formação da Liga das Nações, estadistas progressistas e administradores coloniais passaram a ver o imperialismo europeu começando uma fase de responsabilidade pelo desenvolvimento econômico e social dos povos colonizados. Idéias relativas à confiança, missão e mandato surgiram e substituíram velhas tradições cristãs de paternalismo para com povos atrasados e mais pobres ${ }^{87}$ Embora gastos coloniais com desenvolvimento de infra-estrutura e bem-estar social não tivessem aumentado durante os anos de restrição fiscal que seguiram à Grande Guerra, a percepção de que as responsabilidades supranacionais inevitavelmente custariam mais aos pagadores de impostos na Europa levou a uma nova onda de questionamento e escritos sobre o tema “Os Impérios pagam?". Com a difusão da democracia na Europa, as pessoas começaram a perceber e votar baseadas no pressuposto de que os impérios podem não pagar e uma enxurrada de artigos escritos por jornalistas e intelectuais, expondo os custos, as injustiças e brutalidades ocasionais do domínio colonial, fortaleceram suas dúvidas sobre o valor e o sentido de toda o empreendimento imperial..$^{88}$

\section{DESCOLONIZAÇÃO E OS LEGADOS MALIGNOS DOS IMPÉRIOS EUROPEUS ALÉM-MAR}

A guerra mundial de 1939 a 1945 adiou as discussões sobre o sentido dos impérios europeus. Durante esse conflito, os poderes do Eixo sofreram uma total derrota e perderam, sem nenhuma compensação, todas as custosas conquistas de patrimônios nacionais seguidas de anos (no caso italiano) e décadas de investimento em infra-estrutura de defesa e ordem interna, formação de capital fixo na agricultura, indústria e serviços coloniais e gastos na aculturação, treinamento e educação, requeridos pelos trabalhadores locais a fim de estabelecer uma relação produtiva e comercial estável entre a metrópole e suas colônias. Nem a Itália, nem Alemanha (ou Japão) recuperaram mais do que uma fração de seus investimentos em colonização. Existem poucas dúvidas de que, exceto talvez em termos psicológicos, os benefícios materiais acumulados obtidos pelas sociedades italiana, alemã (e japonesa), por seu

87 HAVINDEN, M.; MEREDITH, D. Colonialism and development: Britain and its tropical colonies 1850-1960. 1993.

88 KOPCHAN, op. cit. 
envolvimento com impérios além-mar, ficaram aquém dos custos de conquista e investimento na infra-estrutura colonial por uma larga margem. Felizmente, gastos fiscais e investimentos públicos e privados parecem não ter sido maciços e prolongados o suficiente para ter restringido, em grau significativo, as taxas de crescimento econômico de longo prazo.

Para outros países europeus, incluindo França, Holanda, Bélgica e Portugal, com longa tradição de colonização e culturas permeadas pelo imperialismo, as tendências rumo a uma integração mais profunda entre as economias domésticas e coloniais, que tinham ressurgido no período entreguerras, tornaram-se mais fortes e mais populares, convertendo-se numa das mais malignas heranças políticas da segunda guerra mundial. ${ }^{89}$ Por exemplo, o envolvimento dos Estados francês, holandês e português nas guerras, a fim de recuperar e pacificar seus impérios de movimentos nacionalistas coloniais no Marrocos, Tunísia, Argélia, Indochina, Congo, Angola, Moçambique e em outros locais fora da Europa, acabaram sendo fúteis e muito dispendiosos. Quando todas as contas forem feitas, os gastos com uma longa série de ações tardias de retaguarda dos exércitos e marinhas européias na África, Ásia, Oriente Médio e Pacífico, certamente serão apresentados como "todos os custos e nenhum benefício". Essa conclusão será reforçada quando os historiadores adicionarem ao legado não-lucrativo das tentativas de renovação imperial as conjecturas sobre o valor econômico da propriedade metropolitana destruída e expropriada pelos movimentos nacionalistas, além dos custos da desordem e depressão que invariavelmente afetaram as antigas economias coloniais por muitos anos depois das suas lutas armadas para conquistar independência (Argélia se tornou simplesmente mais um caso dramático em questão)..$^{90}$

Tendo em vista o tamanho de seu império, a descolonização pelo Reino Unido se tornou menos dispendiosa do que a de outras potências. Mais ainda, a Grã-Bretanha, mais do que qualquer outra nação européia, usou pesadamente os recursos de suas colônias e ex-colônias para derrotar a Alemanha (na área da libra esterlina), com o intuito de dar assistência à sua economia na recuperação após a segunda guerra mundial. ${ }^{91}$ Entretanto, a contribuição imperial para a vitória na Europa e a segurança de seu reino na

89 HOLLAND, R. F. European decolonization, 1918-81. Basingstoke, 1985. 90 LYNCH, F. M. B. France and international economy. 1997.

91 DARWIN, J. Britain and decolonization. The retreat from empire in the post-war world Basingstoke, 1988. 
recuperação pós-guerra precisam ser comparadas com os recursos para participação na guerra supridos pelo próprio reino, pela Rússia e outros aliados, acima de tudo os Estados Unidos. Historiadores podem muito bem considerar qualquer tentativa de estabelecer distinções entre defesa imperial e nacional como discutível. Os economistas, por sua vez, sugerirão realisticamente que os domínios da Grã-Bretanha e suas colônias participaram de uma "aliança virtual" de unidades políticas quase autônomas, construídas e financiadas para proteger suas próprias independências e integridade contra intenções predatórias da Alemanha e Japão..$^{92}$ Se esta "representação economicista" é válida, então a contribuição imperial deve ser descrita sem hesitação como altruísta e importante para a sobrevivência e desenvolvimento contínuo da Grã-Bretanha e França durante as guerras mundiais do século XX. Mais ainda o legado cultural do imperialismo, que credenciou e deu suporte ao entendimento, repetidamente enfatizado, de que o significado material do império pode, no final do século, ser representado como uma restrição persistente para os ajustes necessários para a vitalidade competitiva da economia britânica. ${ }^{33}$ Por exemplo, a herança do império permeou a formulação de políticas estratégicas, fiscal, monetária e comercial do reino de tal forma que retardou e castigou a adaptação da economia à realidade de poder e competição internacional depois de $1945 .{ }^{94}$ Apenas Portugal e, numa extensão menor, França parecem ter sido economicamente afetados (e não no mesmo grau) pelas heranças culturais e políticas do império. ${ }^{95}$

Quanto economicamente superior a moderna História teria se tornado para a Grã-Bretanha e o resto da Europa imperial se as recomendações de Cobden e Hobson para a separação dos impérios tivessem sido seguidas no final do século XIX ao invés do final do turbulento século XX? Entretanto, $o$ argumento desse ensaio tem a preocupação de desafiar a percepção comum de que as economias européias obtiveram ganhos com a conquista e colonização da África, Ásia e América do Sul que foram de alguma forma indispensáveis ou, no mínimo, enormemente significativos para o desenvolvimento de longo prazo daquelas economias.

92 OFFER, 1993, op. cit.

93 FEINSTEIN, C. F. The end of empire and the golden age. In: CLARKE, P.; TREBILCOCK, C. (Ed.). Understanding decline. Cambridge, 1997. p. 212-233.

94 WEBB, M. C. The political economy of policy coordination: international adjustment since 1945. Ithaca, 1995.

95 LYNCH, op. cit. 
Concluindo deve ser interessante colocar algumas especulações relacionadas às razões pelas quais o imperialismo acabou sendo menos lucrativo para vários estados europeus mais ativamente e consistentemente envolvidos em empreendimentos e expansão além-mar.

O fato de os governos europeus, juntamente com investidores privados, persistirem com várias formas de domínio colonial por quase cinco séculos, provavelmente fez crer que suas políticas e ações seriam recompensadas. Expressando uma sabedoria baseada no fato consumado, os historiadores sugerem agora que os estadistas, os generais, almirantes, projetistas, empresários e investidores envolvidos na promoção dos empreendimentos imperialistas europeus subestimaram os gastos e os riscos inerentes. Os custos da conquista freqüentemente se tornavam maiores do que o previsto inicialmente. As perspectivas de pilhagem estimulavam aventuras além-mar e resultavam em imediatos e, algumas vezes, grandes ganhos. Entretanto, a pacificação e persistente coerção de populações nativas desmantelaram a base econômica para uma exploração de longo prazo de recursos naturais, mercadorias e mercados que os europeus esperavam converter em fluxos de benefícios materiais para si mesmos, suas sociedades e seus poderes, na ordem internacional de estados competidores. ${ }^{96}$

Mais ainda, até recentemente, os governos europeus, comerciantes e homens de negócio falharam em manter seus investimentos em níveis próximos aos necessários para a formação de infra-estrutura e capital humano para assegurar que seus domínios políticos sobre as populações coloniais, recursos naturais e patrimônios subexplorados na África, Ásia e América Latina se tornassem realmente lucrativos. A América do Norte foi uma outra história, mas a descoberta e exploração desse subcontinente acabaram concentrando os investimentos europeus em outras regiões da economia mundial.

Enquanto isso, por duas razões, os custos do domínio colonial (incluindo a coerção e a extensão dos incentivos concebidos para assegurar a colaboração entre os colonizados e os colonizadores) aumentaram ao longo do tempo. Mesmo entre os mais implacáveis dos estados europeus, a capacidade de controle permaneceu geograficamente, politicamente e economicamente restringida pelos recursos e instrumentos à sua disposição para o exercício do poder. Quando as tecnologias para governos mais fortes e mais ousados gradualmente melhoraram, eles passaram a enfrentar uma crescente resistência de movimentos nacionalistas pela emancipação colonial, a qual elevou os custos da coerção no interior dos impérios e também das próprias metrópoles. ${ }^{97}$

96 LANDES, D. The wealth and poverty of nations. 1998.

97 LIBERMAN, P. Does conquest pay? Princeton, 1996. 
Resistências locais certamente importavam, particularmente quando chegou o momento da partida e quando a relutância em deixar as colônias, por parte de alguns governos europeus, implicou numa rodada final de elevados custos para as economias das metrópoles. Finalmente, ao longo dos cinco séculos ou mais de expansão européia além-mar, o contexto da política de grande potência, no qual o imperialismo aconteceu, acabou promovendo rivalidade, mercantilismo e guerra entre os estados, o que é talvez a principal razão pela qual os ganhos potenciais oriundos da expansão européia alémmar, colonização e comércio foram dissipados, o que parece tão decepcionante neste final do século XX.

\begin{abstract}
This paper surveys a growing volume of publications with a view to assessing the costs and benefits of five centuries of European involvement with empires overseas. Therefore, attention is paid to the tradition of political debate and to the historical discourse regarding 'outlays' and 'returns' flowing from formal imperialism. The paper focuses on the costs and benefits of empires for the economic growth of several European economies during 1815-1914. It also analyses the subsequent period of imperial reintegration and decolonization, inaugurated by two world wars in the twentieth century.
\end{abstract}

\title{
RESUMO
}

Este artigo é uma revisão do crescente volume de publicações sobre os custos e benefícios, para as economias européias, de cinco séculos de envolvimento com impérios ultramarinos. Para isso, é dada atenção à tradição do debate político e ao discurso histórico relativos às 'despesas' e 'retornos' do imperialismo formal. Este artigo se concentra nos custos e benefícios dos impérios para o crescimento de longo prazo de algumas economias européias durante o período de 1815-1914. Também são analisados os períodos subseqüentes de reintegração e descolonização, inaugurada pelas duas guerras mundiais no século XX. 


\section{REFERENCIAS}

ADAS, M. (Ed.). Machines as the measure of men: science, technology and ideologies of western dominance. Ithaca, 1989.

ALFORD, B. Britain in the world economy since 1880. Harlow, 1996.

BAINES, D. Emigration from Europe. Basingstoke, 1991.

BAIROCH, P. Commerce extérieur et développement economique de l'Europe au XIXe siècle. Paris, 1976.

. Economics and world history: myths and paradoxes. Hemel Hempstead, 1993.

BALFOUR, S. The end of the Spanish empire, 1898-1923. 1997.

BARRATT-BROWN, M. The economics of imperialism. 1974.

BARRETT, W. World bullion flows. In: TRACY, J. (Ed.). The rise of merchant empires. Cambridge, 1990. p. 224-234.

BECKETT, J.; GOOCH, J. (Ed.). Politicians and defence: studies in the formulation of British defence policy. Manchester, 1981.

BETTS, R. F. Europe overseas: phases of imperialism. New York, 1968.

France and decolonization. 1991.

BLAUT, J. The colonizers: model of the world. New York, 1993.

BOGART, E. L. Direct and indirect costs of the great war. New York, 1919.

BRAUDEL, F. The perspective of the world. 1979.

BROADBERRY, S. N. The productivity race. Cambridge, 1997.

BUTEL, P. France, the Antilles and Europe in the seventeenth and eighteenth centuries: renewals of foreign trade. In: TRACY, J. (Ed.). The rise merchant empires. Long distance trade in the early modern world. Cambridge, 1990. p. 153-174.

BUTEL, P.; CROUZET, F. Empire and economic growth: the case of France. Revista de Historia Económica, v. 1, p. 177-194, 1998.

BRUNSCHWIG, H. Mythes et realités de l'imperialisme colonial Francais. Paris, 1960.

CAIN, P. Was it worth having? The British empire 1850-1950. Revista de Historia Económica, v. 16, p. 351-376, 1998.

CAIN, P.; HOPKINS, A. G. British imperialism crisis and deconstruction. 1993.

CAPIE, F. Tariffs and growth: some illustrations from the world economy 1850-1940. Manchester, 1994.

CLARENCE-SMITH, W. G. The economic dynamics of Spanish colonialism in the nineteenth and twentieth centuries. Itinerario, v. 1, p. 71-88, 1991.

CLARK, G. The balance sheet of imperialism. New York, 1936.

CRAFTS, N. F.; TONIOLO, G. (Ed.). Economic growth in Europe since 1945. Cambridge, 1996.

CUENCA ESTEBAN, J. The rising share of British industrial exports in industrial output, 1700-1851. Jnl. Econ. Hist., n. 57, p. 879-906, 1997. 
DAVIS, L. E.; HUTTENBACK, R. A. Mammon and the pursuit of empire. The political economy of British imperialism. Cambridge, 1986.

DARWIN, J. Britain and decolonization. The retreat from empire in the post-war world. Basingstoke, 1988.

DE VRIES, J.; VAN DER WOUDE, A. The first modern economy. Success and perseverance of the dutch economy. Cambridge, 1997.

DORMOIS, J. P.; CROUZET, F. The significance of the French colonial empire, for French economic development. Revista de Historia Económica, v. 16, p. 291-322, 1998.

DOYLE, W. Empires. Ithaca, 1986.

EDELSTEIN, M. Imperialism: cost and benefit. In: FLOUD, R.; McCLOSKEY, D. (Ed.). The Economic History of Britain since 1700. Cambridge, 1994. v. 2, p. 197-216.

EMMER, P. C. The economic impact of the Dutch expansion overseas 1570-1870. Revista de Historia Económica, v. 16, p. 157-176, 1998.

ENGERMAN, S. L. British imperialism in a mercantilist age 1492-1849: conceptual issues and empirical problems. Revista de Historia Económica, v. 16, p. 195-234, 1998.

FEDERICO, G. Italy's late and unprofitable forays into empire. Revista de Historia Económica, v. 16, p. 377-402, 1998.

FIELDHOUSE, D. K. Colonial empires since the eighteenth century. New York, 1967. Economics and empire. 1973.

FEINSTEIN, C. F. (Ed.). Banking, currency and finance in Europe. Oxford, 1995.

The end of empire and the golden age. In: CLARKE, P.; TREBILCOCK, C. (Ed.). Understanding decline. Cambridge, 1997.

FISCHER, W.; McINNIS, R. M.; SCHNEIDER, J. (Ed.). The emergence of a world economy 1500-1850. Stuttgart, 1986.

FITZGERALD, E. P. Did France's colonial empire make economic sense? A perspective from the postwar decade 1946-56. Jnl. Econ. Hist., v. 48, p. 373-385, 1988.

FLYNN, D.; GIRALDEZ, A. (Ed.). Metals and monies in an emerging global economy. Aldershot, 1996.

FORSYTH, P. J.; NICHOLAS, S. J. The decline of Spanish industry and the price revolution: a neo-classical analysis. Jnl. Eur. Econ. Hist., p. 601-610, 1983.

FRAILE, B. P. Industrialización y grupos de presión. La economía política de la protección en España. Madrid, 1991.

FRAILE, P.; ESCRIBANO, A. The Spanish 1898 disaster: the drift towards national protectionism. Revista de Historia Económica, v. 16, p. 265-290, 1998.

FRENCH, D. The British way of warfare, 1688-2000. 1990.

GOMES, L. Foreign trade and the national economy. 1987.

HAVINDEN, M.; MEREDITH, D. Colonialism and development: Britain and its tropical colonies 1850-1960. 1993.

HOBSON, C. K. Imperialism. Ann Arbor, 1967.

HOBSON, J. A. The wealth of states. Cambridge, 1997. 
O'BRIEN, P. K.; DE LA ESCOSURA, L. A expansão dos impérios europeus...

HOLLAND, R. F. European decolonization, 1918-81. Basingstoke, 1985.

JOHNS, R. A. Colonial trade and international trade. 1988.

JONES, E. L. The European miracle. Cambridge, 1981. p. 104-153.

KENNEDY, P. The rise and fall of British naval mastery. 1983.

The rise and fall of the great powers. London, 1988.

KENNEDY, W. P. Industrial structure, capital markets and the origins of British economic decline. Cambridge, 1987.

KEYLOR, W. R. The twentieth century world. Oxford, 1984.

KOPCHAN, C. A. The vulnerability of empire. 1994.

LAINS, P. An account of the Portuguese African empire. Revista de Historia Económica, v. 16, p. 235-264, 1998.

. A Econômica Portuguesa no século XIX. Lisboa, 1995.

LANDES, D. The wealth and poverty of nations. 1998.

LIBERMAN, P. Does conquest pay? Princeton, 1996.

LIPSON, C. Standing guard: protecting foreign capital in the nineteenth and twentieth centuries. Berkeley, 1985.

LYNCH, F. M. B. France and international economy. 1997.

MAIER, C. Recasting bourgeois Europe. Princeton, 1975.

. In search of stability: explorations in historical political economy. Cambridge, 1987.

MALUQUER DE MOTE, J. El mercardo colonial antillano en el siglo XIX. In: NADAL, J.; TORELLA, G. (Ed.). Agricultura, comercio colonial y crecimiento económico en la España contemporánea. Barcelona, 1974. p. 64-73.

NUNEZ, C. E. (Ed.). Debates and controversies in economic history. Madrid, 1998.

O'BRIEN, P. K.; ENGERMAN, S. L. Exports and the growth of the British economy from the Glorious Revolution to the Peace of Amiens. In: SOLOW, B. (Ed.). Slavery and the rise of the Atlantic system. Cambridge, 1991. p. 177-209.

. The security of the realm and the growth of the economy 1688-1914. In: CLARKE, P.; TREBILCOCK, C. (Ed.). Understanding decline. Cambridge, 1997. p. 61-72.

Intercontinental trade and the development of the third world since the industrial revolution. Jnl. World. Hist, n. 8, p. 75-133, 1997.

. Inseparable connections: trade, economy, fiscal state and the expansion of empire. In: MARSHALL, P. (Ed.). The Oxford history of the British empire. Oxford, 1998. v. 2, p. 53-78.

OFFER, A. The British empire: a waste of money? Econ. Hist. Rev., n. 45, p. 215-238, 1993.

. The First World War: an agrarian interpretation. Oxford, 1989.

. Costs and benefits, peace and war 1870-1914. In: PORTER, A. (Ed.). The Oxford history of the British empire. Oxford, 1999. p. 690-711.

PARKER, G. Europe and the wider world 1500-1700: the miliary balance. In: TRACY, J. (Ed.). The political economy of merchant empires. Cambridge, 1991. p. 161-195. 
PEREIRA, J. M. La economía portuguesa y el fin del imperio luso brasileño. In: PRADOS DE LA ESCOSURA, L.; AMARAL, S. (Ed.). La independencia americana: consecuencias. Madrid, 1993. p. 219-252.

. To have and to have not. The economic consequences of empire. Revista de Historia Económica, v. 16, p. 93-122, 1998.

PIEPER, R. The volume of African and American exports of precious metals and its effects in Europe, 1500-1800. In: POHL, H. (Ed.). The European discovery of the world and its economic effects on pre-industrial society. Stuttgart, 1990. p. 97-121.

PORTER, B. Critics of Empire. 1968.

PRADOS DE LA ESCOSURA, L. De imperio a nación: cremimiento y atraso económico en España 1780-1830. Madrid, 1988.

PRADOS DE LA ESCOSURA, L.; AMARAL, S. (Ed.). La independencia americana: consecuencias económicas. Madrid, 1993.

REYNOLDS, L. G. Economic growth in the third world, 1850-1980. 1985.

ROGOWSKI, R. Commerce and coalitions: how trade effects domestic political arrangements. Princeton, 1989.

RUSSELL-WOOD, J. R. (Ed.). An expanding world. The European impact on world history 1450-1800. Aldershot, 1995.

SÁNCHEZ ALONSO, B. Las causas de la emigración española 1880-1930. Madrid, 1995.

SNYDER, J. Myths of empire. Domestic politics and international ambition. Ithaca, 1991.

STEENSGAARD, N. Commodities, bullion and services in intercontinental transactions before 1750. In: POHL, H. (Ed.). The European discovery of the world and its economic effects on pre-industrial society. Stuttgart, 1990. p. 9-24.

THOMPSON, I.; YUN-CASALILLA, B. (Ed.). The Castillian crisis of the seventeenth century. Cambridge, 1994.

THORNTON, A. K. The imperial idea and its enemies. 1959.

TILLY, C. Coercion, capital and states. Oxford, 1990.

TONIOLO, G. L'economia dell'Italia facista. Bari, 1980.

TRACHTENBERG, M. Reparations in world politics: France and European economic diplomacy. New York, 1980.

VAN DER ENG, P. Exploring exploitation: the Netherlands and colonial Indonesia, 18701939. Revista de Historia Económica, v. 16, p. 235-264, 1998.

VAN DER WEE, H. Prosperity and upheaval: the world economy, 1948-80. 1986.

WEBB, M. C. The political economy of policy coordination: international adjustment since 1945. Ithaca, 1995.

WILLIAMSON, G. W. Globalization convergence and history. Jnl. Econ. Hist., n. 56, p. 277-306, 1996.

WOOD, J. C. British economists and empire. 1993.

YUN-CASALILLA, B. The American empire and the Spanish economy: an institutional and regional perspective. Revista de Historia Económica, n. 1, p. 123-157, 1998.

ZIEBERG, G. World economy and world politics. Oxford, 1990. 
